\title{
STUDIES OF THE CHEMICAL DURABILITY OF GLASS BY AN INTERFEROMETER METHOD
}

\author{
By Donald Hubbard and Edgar H. Hamilton
}

\begin{abstract}
An interferometer method for determining the chemical durability of glass has been tried on a series of typical glasses over a wide range of temperature and $\mathrm{pH}$. The results emphasize the importance of careful temperature control if comparisons are to be made between the findings of different investigators. The relations between amount of attack and $\mathrm{pH}$ for some of the glasses show pronounced inflections near $\mathrm{pH} 7$ in the presence of Britton universal buffer, while the attack by distilled water for these same glasses is very slight in comparison. Moreover, the results strongly emphasize the fact that there can be no single test by which the durability of glass can be judged with respect to all conditions
\end{abstract} of service.

The method has proved particularly useful in the interpretation of known voltage anomalies of the glass electrode.

\section{CONTENTS}

I. Introduction _.

II. Experimental procedure _...

III. Durability of glasses under various conditions_._.

1. Effect of duration of exposure at constant temperature ...... 145

2. Effect of temperature for constant periods of exposure_._..... 146

3. Durability at different $\mathrm{pH}$ values . . ...................... 149

4. Effect of increased sodium-ion concentration on chemical dur-

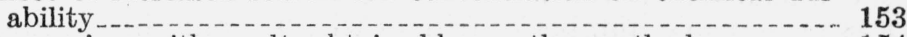

5. Comparison with results obtained by another method....... 154

6. Comparison of durability in the presence of sodium and potassium hydroxides.......... 156

IV. Summary _...

V. References

\section{INTRODUCTION}

Of the many methods proposed for determining the relative "chemical durability" of glasses none has met with universal approval and none is completely fair to all types of glasses [1]. ${ }^{1}$ The present paper reports the results of direct measurement, by means of an interferometer, of the rates of attack of several types of glass by various reagents over a wide range of conditions of temperature, time, and $\mathrm{pH}$. If durability is defined as the resistance of glass to attack by a specified reagent, the method herein described provides a simple way of determining it in those instances in which the attack is relatively rapid.

Although the interferometer method $[2,3,4,5]$ as thus far used is not highly precise or accurate, it does yield results which appear to give a clearer picture of the durability of glasses over a much wider range of conditions than any of the methods previously proposed.

1 Figures in brackets indicate the literature references at the end of this paper. 


\section{EXPERIMENTAL PROCEDURE}

The specimens of glass were rectangular, approximately 2 by $3 \mathrm{~cm}$, with surfaces sufficiently flat to show interference bands when placed under a slab of optically flat fused quartz. These specimens were partially immersed approximately one-third of their length in the desired solution, the surface of which was covered throughout the period of the test with a thin layer of liquid petrolatum to prevent evaporation. All the durability tests were made in Pyrex beakers. The desired temperature was maintained within $\pm 0.2^{\circ} \mathrm{C}$ by means of an electrically heated water bath. Uniform attacks upon the immersed surfaces were obtained, except that, under certain conditions, a more pronounced attack occurred just at the oil-solution interface than elsewhere. The resulting indentations are referred to in table 4 as "surface cuts." At the end of the period of the treatment the specimens were removed and rinsed, first in dilute acid and then in water to stop further attack.

The magnitude of the attack, that is the thickness of glass dissolved away, or the thickness added by swelling, was determined by observing the displacement of the interference fringes when the specimen was placed under a fused quartz optical flat. The quartz flat in this case must have both surfaces polished "true plane" and adjusted to make an angle of $20^{\prime \prime}$ with each other, so that the light reflected from the upper surface will not be reflected back to the observer. The observations were made with the conventional Pulfrich viewing apparatus, using an unfiltered helium lamp for illumination. The values were recorded to a quarter of a fringe with a further gradation of + and to designate that the attack was slightly more or less than the recorded value. Greater precision might be obtained with a micrometer eyepiece. For very small attacks, "detectable" and 1/10 fringe were also used to express the degree of alteration of the surface. If the specimens are viewed with monochromatic light, there is no indication as to the whole number of fringes which should be counted to measure the degree to which the surface has been altered. However, with the filter removed, the color pattern for the fringes in the unattacked portion of the specimen persists in the attacked area, making the total amount of shift readily apparent. Furthermore, without the filter it is easy to determine whether the specimen has swollen or has been dissolved away during the exposure to the solution, by observing the direction of shift of the interference bands. Each band displacement is approximately equivalent to an attack of 0.29 micron. Although in these experiments the determinations were made with the Pulfrich viewing apparatus, equally satisfactory results can be obtained with a simple 25-watt incandescent light mounted in any convenient housing for shielding the eyes from the direct glare. With this illumination and with the aid of a hand magnifying glass for viewing the bands, the observations can be made as conveniently as, or perhaps more conveniently than, with the more expensive Pulfrich apparatus. 


\section{DURABILITY OF GLASSES UNDER VARIOUS CONDITIONS}

\section{EFFECT OF DURATION OF EXPOSURE AT CONSTANT TEMPERATURE}

In table 1 are listed the attacks in interference bands for five commercial glasses and three optical glasses resulting from treatment with 5-percent $\mathrm{NaOH}$ (sodium hydroxide) at $80^{\circ} \mathrm{C}$ for various time intervals ranging from 15 minutes to 6 hours. These data, as plotted in figure 1, indicate that the reduction in thickness of each glass was directly proportional to the duration of treatment. The rates of attack for the different glasses, listed as $a$ in column 2 of table 3, could

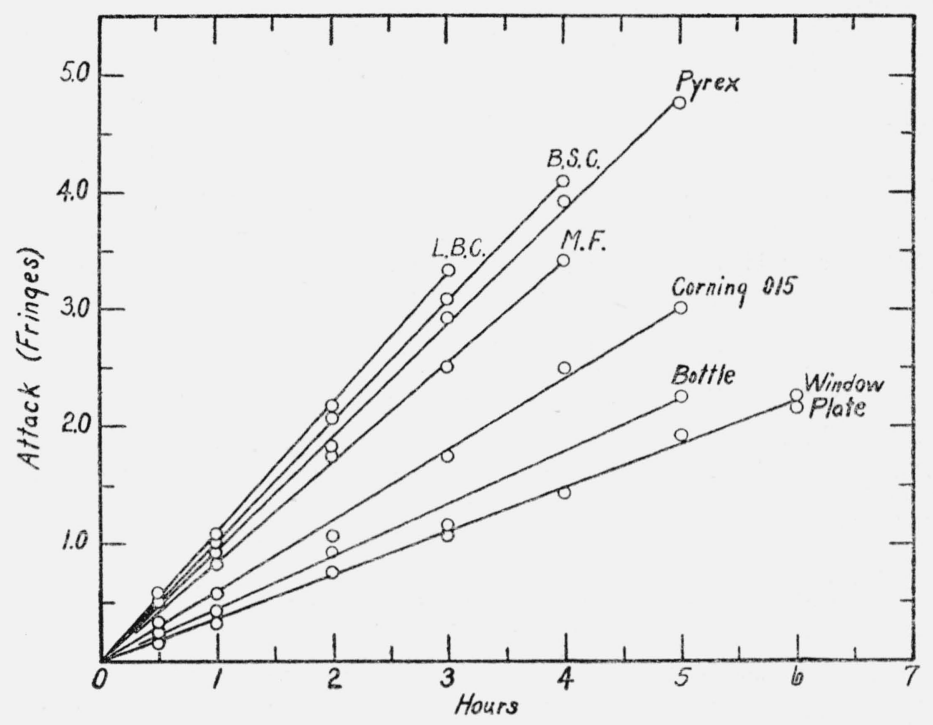

FIGURE 1.-Attack-time plot for eight types of glasses exposed to 5-percent $\mathrm{NaOH}$ at $80^{\circ} \mathrm{C}$.

be used to represent the relative order of durability of these glasses with respect to this solution at the specified temperature. However, since the chemical durability of the glasses decreases with increasing slopes, it is perhaps desirable to take the reciprocals of these values in order that the glasses with the better chemical durabilities may be represented by the larger numerical values. The chemical durability of glass under these conditions could thus be defined as the time required for one unit (fringe) change of thickness, or

Chemical durability $=1 / a$, where $a=\frac{\text { attack in fringes }}{\text { time in hours }}$.

Values of $1 / a$ are given in column 3 of table 3. 
TABLE 1.-Attack in terms of interference bands by 5-percent $\mathrm{NaOH}$ at $80^{\circ} \mathrm{C}$ on eight types of glass

\begin{tabular}{|c|c|c|c|c|c|c|c|c|}
\hline Time & Plate & Window & $\begin{array}{l}\text { Am. Cer. } \\
\text { Soc. bot- } \\
\text { tle No. } 1\end{array}$ & $\begin{array}{c}\text { Corning } \\
015\end{array}$ & M. F. ${ }^{1}$ & $\begin{array}{c}\text { Chemical } \\
\text { Pyrex }\end{array}$ & B. S. C. 1 & L. B. C.1 \\
\hline $\begin{array}{l}15 \text { minutes. } \\
30 \text { minutes.... } \\
1 \text { hour } \\
2 \text { hours } \\
3 \text { hours } \\
4 \text { hours } \\
5 \text { hours } \\
6 \text { hours. }\end{array}$ & $\begin{array}{r}\text { Fringes } \\
<1 / 10 \\
>1 / 10 \\
1 / 4+ \\
3 / 4 \\
1+ \\
11 / 2- \\
2- \\
21 / 4-\end{array}$ & \begin{tabular}{|r|} 
Fringes \\
$1 / 4+$ \\
$3 / 4$ \\
$11 / 4-$ \\
$11 / 2-$ \\
$2-$ \\
$21 / 4$
\end{tabular} & $\begin{array}{r}\text { Fringes } \\
1 / 2- \\
1- \\
21 / 4\end{array}$ & $\begin{array}{r}\text { Fringes } \\
1 / 4 \\
1 / 2+ \\
1+ \\
13 / 4 \\
21 / 2 \\
3\end{array}$ & $\begin{array}{r}\text { Fringes } \\
344- \\
144 \\
344+ \\
134 \\
21 / 2 \\
31 / 2- \\
\end{array}$ & $\begin{array}{r}\text { Fringes } \\
1 \% / 2 \\
1- \\
13 / 4+ \\
3- \\
4- \\
43 / 4\end{array}$ & $\begin{array}{r}\text { Fringes } \\
1 / 4 \\
1 / 2 \\
1 \\
2+ \\
3+ \\
4+ \\
-\end{array}$ & $\begin{array}{r}\text { Fringes } \\
1 / 4+ \\
1 / 2+ \\
1+ \\
2144 \\
314+ \\
\hdashline\end{array}$ \\
\hline
\end{tabular}

1 M. F.; B. S. C.; and L. B. C. are optical glasses: medium flint, borosilicate crown, and light barium crown, respectively.

TABLE 2.-Atiack in interference bands by 5-percent $\mathrm{NaOH}$ for 3 hours at various temperatures

\begin{tabular}{|c|c|c|c|c|c|c|c|c|}
\hline Temperature ${ }^{\circ} \mathrm{C}$ & Plate & Window & $\begin{array}{l}\text { Am. Cer. } \\
\text { Soc. bot- } \\
\text { tle No. } 1\end{array}$ & $\begin{array}{c}\text { Corning } \\
015\end{array}$ & M. F. ${ }^{1}$ & $\begin{array}{c}\text { Chemical } \\
\text { Pyrex }\end{array}$ & B. S. C. 1 & L. B. C. 1 \\
\hline $\begin{array}{l}30 \\
40 \\
50 \\
70 \\
80\end{array}$ & $\begin{array}{c}\text { Fringes } \\
110- \\
1 / 10+ \\
1 / 4 \\
1 / 2+ \\
1+ \\
2+\end{array}$ & $\begin{array}{r}\text { Fringes } \\
1 / 10+ \\
1 / 4 \\
1 / 2+ \\
11 / 4- \\
2+\end{array}$ & $\begin{array}{c}\text { Fringes } \\
1 \mathrm{D} \\
1 / 10+ \\
1 / 4+ \\
3 / 4 \\
11 / 2- \\
3-\end{array}$ & $\begin{array}{r}\text { Fringes } \\
\mathrm{D} \\
1 / 10+ \\
1 / 4+ \\
1-3 \\
13 / 4 \\
>3,<4\end{array}$ & $\begin{array}{r}\text { Fringes } \\
\mathrm{D}^{2} \\
1 / 10 \\
1 / 1-? \\
11 / 2+ \\
11 / 4 \\
21 / 2\end{array}$ & \begin{tabular}{|r|} 
Fringes \\
$11 / 10$ \\
$1 / 4$ \\
$1 / 2+$ \\
$11 / 2-$ \\
$3-$ \\
$>5,<6$
\end{tabular} & $\begin{array}{r}\text { Fringes } \\
\mathrm{D} \\
1 / 10+ \\
1 / 4+ \\
3 / 4 \\
1.1 / 4 ? \\
3+\end{array}$ & $\begin{array}{r}\text { Fringes } \\
1 / 10- \\
3100 \\
1 / 2- \\
3 / 4+ \\
134- \\
314\end{array}$ \\
\hline
\end{tabular}

1 M. F.; B. S. C.; and L. B. O. are optical glasses: medium flint, borosilicate crown, and light barium crown, respectively.

$2 \mathrm{D}$, detectable.

3 Poor cut.

TABLE 3.-Values of the constants $a$ and $b$ from the data in table 1 and table 2 for 5-percent $\mathrm{NaOH}$ solution

[(1) Attack at $80^{\circ} \mathrm{C}=a \times$ hours; (2) Attack $/$ hours $\left.=b \times(2) t / 10\right]$

\begin{tabular}{|c|c|c|c|}
\hline Glass & $a$ & $1 / a$ & $b^{1}$ \\
\hline & Fringes/hour & Hours/fringe & Fringes/hour \\
Plate. & 0.37 & 2.70 & 0.014 \\
Window. & .37 & 2.70 & .0014 \\
Am. Cer. Soc. Bottle No.1. & .13 & .0018 \\
Corning 015... & .47 & .0023 \\
M. F.2. & .59 & .0033 \\
Chomical Pyrex. & .83 & .003 \\
B. S. C.2 & .95 & .00 & .0040 \\
L. B. C.2. & 1.02 & .91 & .0043 \\
\hline
\end{tabular}

1 Inspection of the constant $b$ shows it to be the attack in fringes (extrapolated to $0^{\circ} \mathrm{d}$ ) for 1 hour's exposure to 5-percent $\mathrm{NaOH}$ solution. Hence an intercomparison of the constants $a$ and $b$ can be had by the simplo

relation $a=b \times(2)^{80 / 10}$.
2 M. F.; B. S. C.; and L. B. C. are optical glasses: medium flint, borosilicate crown, and light barium crown, respectively.

\section{EFFECT OF TEMPERATURE FOR CONSTANT PERIODS OF EXPOSURE}

The attack of glass by aqueous solutions as ordinarily observed has to do with a rate of reaction; hence the term "solubility", which means strictly the quantity of a substance which will dissolve in a given quantity of a solvent at a specified temperature, when equilibrium is attained, should not be used in this connection. Further- 
more, the reaction whose rate as observed is not necessarily a process of solution only, but it may involve solution of some constituent, followed by mechanical removal of individual products of decomposition from the affected area. It cannot be too strongly emphasized that this type of reaction is highly sensitive to slight differences in experimental conditions, such as $\mathrm{pH}$ and temperature $[1,4]$. Figure 2 , plotted from the data in table 2 , shows graphically the effect of increasing temperature upon the amount of glass removed by chemical attack during a 3-hour interval in which the same glasses as those reported in figure 1 were exposed to 5-percent $\mathrm{NaOH}$. Within

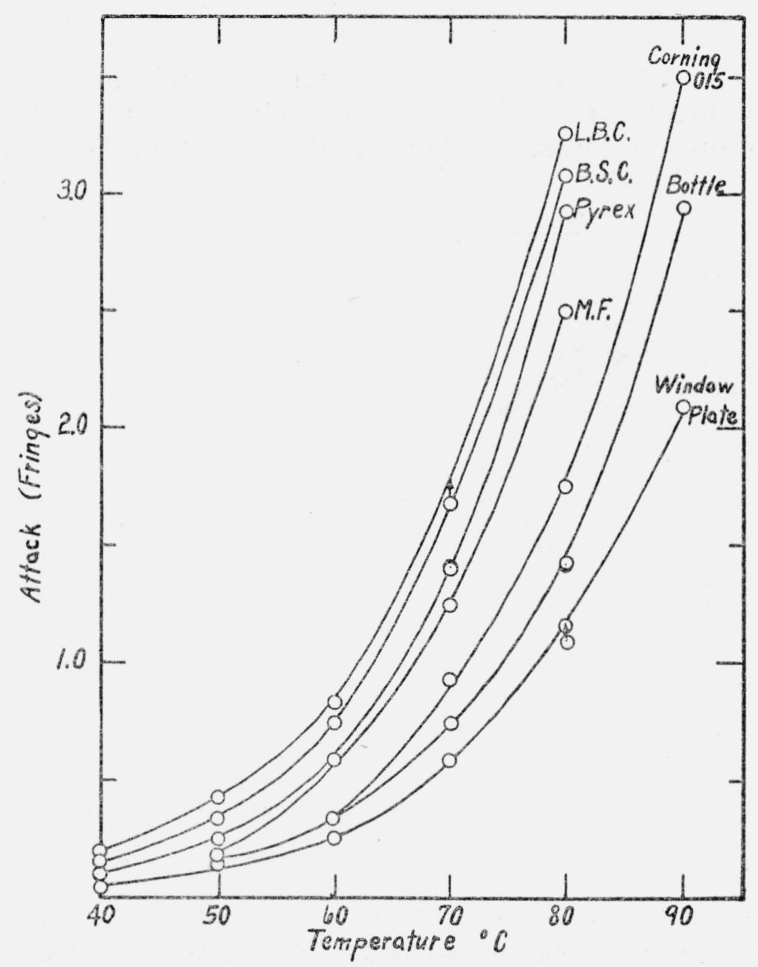

Figure 2.-Temperature effects on rate of attack for eight types of glasses in 5percent $\mathrm{NaOH}$ for 3 hours.

reasonable limits the attack follows the usual approximation that the rate of reaction doubles for each $10^{\circ} \mathrm{C}$ rise in temperature, which relation may be expressed in the equation

$$
\text { Attack/hours }=b \times(2)^{t / 10} \text {, }
$$

where $b$ is a constant and $t$ is temperature in degrees centigrade. This relation must not be considered rigorously accurate, but it does emphasize the importance of very careful temperature control. Values of $b$ which are listed in column 4 of table 3 could be used as an index of relative durability for these glasses in 5-percent $\mathrm{NaOH}$. 
A classical relation is that proposed by Arrhenius [6] and given in the following equation:

$$
\frac{d \ln k}{d T}=\frac{E}{R T^{2}},
$$

in which $k$ is the reaction rate or, in this case, attack on the glass in fringes per unit of time, $E$ is a constant, $R$ is the gas constant, and $T$ is the absolute temperature. Integrating eq 2, we have

$$
\log k=-\frac{E}{2.303 R T}+C=-\frac{B}{T}+C,
$$

where $B=(E / 2.303 R)$ and $C$ is a constant. Geffcken and Berger [5] found this relation to apply to the attack of $\mathrm{Na}_{2} \mathrm{CO}_{3}$ solutions on a borosilicate crown glass. Müller and Weinstein [7] found that it

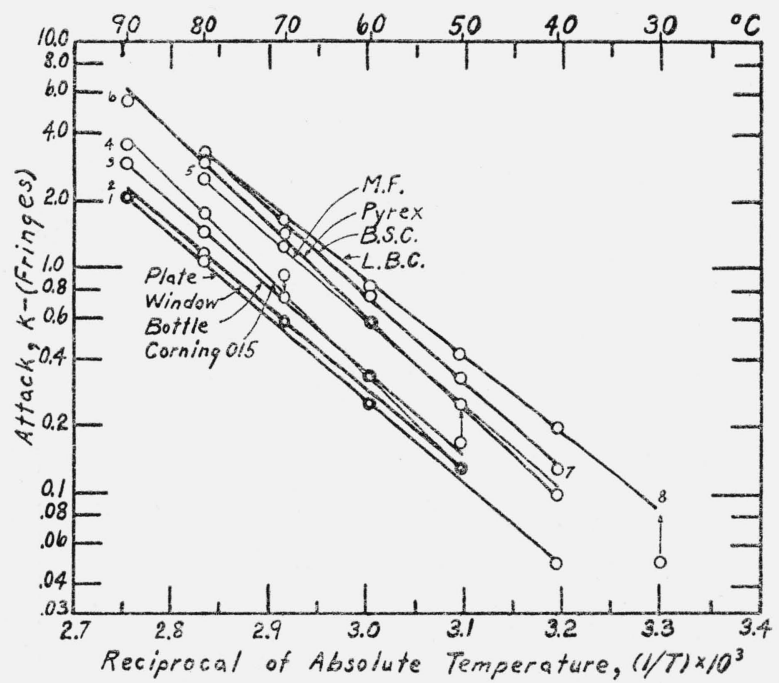

FIgURE 3.-Log attack, $k$, versus reciprocal absolute temperature, $1 / T$.

Cases in which values coincide for different glasses are indicated by heavy walled circles. Temperature in ${ }^{\circ} \mathrm{C}$ inserted for convenience.
1. Plate glass.
2. Sheet glass
3. American Ceramic Society bottle No. 1.
4. Corning 015 glass.
5. Medium flint glass.
6. Pyrex.
7. Borosilicate crown.
8. Light barium crown.

applies to the attack of water on borosilicate glasses when the amount of $\mathrm{B}_{2} \mathrm{O}_{3}$ in the glass is greater than 0.1 percent. Hamilton and Hubbard [8] found that it is also applicable to the attack of water on a number of bottle glasses.

In figure 3 the attack by 5 -percent $\mathrm{NaOH}$ solution in 3 hours on the eight different glasses of table 1 are plotted on a log scale against the reciprocal of the absolute temperature. For each glass these points 
plot as a straight line within the limit of error in determining the amount of attack. The equations for these lines are

Plate glass

Window glass

Am. Ceram. Soc. Bottle No. 1

Corning 015 (glass electrode) glass

Medium flint (optical) glass

Pyrex

Borosilicate crown (optical) glass

Light barium crown (optical) glass

$$
\begin{aligned}
\log k & =-\frac{3600}{T}+10.23 \\
& =-\frac{3600}{T}+10.26 \\
& =-\frac{3960}{T}+11.38 \\
& =-\frac{4280}{T}+12.37 \\
& =-\frac{3870}{T}+11.37 \\
& =-\frac{4020}{T}+11.84 \\
& =-\frac{3700}{T}+10.97 \\
& =-\frac{3320}{T}+9.90
\end{aligned}
$$

In figure 3 some of the lines cross and, with the possible exception of two lines, the slopes of the individual lines are different. These conditions suggest that it may not be safe to use observations made at high temperatures as criteria of chemical durability at room temperature. The order of relative chemical durability of a series of glasses at elevated temperatures may not be the same as at room temperature. Taylor and Smith [9] in their investigation of the chemical durability of various glasses by the powder method found such reversals. On this basis it would seem advisable when water or alkaline solutions are used as the attacking media to make tests at two or more temperatures and then extrapolate the results to room temperatures by the use of graphs such as those in figure 3 .

\section{DURABILITY AT DIFFERENT pH VALUES}

Of special interest is the variation in the chemical durability of glass over a wide $\mathrm{pH}$ range, from acid to highly alkaline solutions. To obtain information on this property, the eight glasses previously described were exposed for 6 hours at $80^{\circ} \mathrm{C}$ to Britton universal buffer solutions [10] having a $\mathrm{pH}$ range from 1.8 to 12 . This range was extended to $\mathrm{pH} 0.65$ with a sodium acetate-hydrochloric acid buffer. The results show an interesting variety in the durability of these glasses (table 4). Three of them show no detectable attack after 6 hours at $80^{\circ} \mathrm{C}$ up to $\mathrm{pH} 7$, beyond which there is a detectable attack at $\mathrm{pH} 8$ and 9 , while with further increase in alkalinity the attack increases rapidly. These three glasses are, respectively, American Ceramic Society bottle glass No. 1 [11], a window glass, 
and Pyrex. The results for these three glasses, which are plotted in figure 4, are typical of many of the commercial silicate glasses. Pyrex is the least resistant of the three at $\mathrm{pH} 11$ and $12[12,1]$ and this difference becomes more pronounced in the high alkalinity of 5 percent $\mathrm{NaOH}$ (figs. 1 and 2).

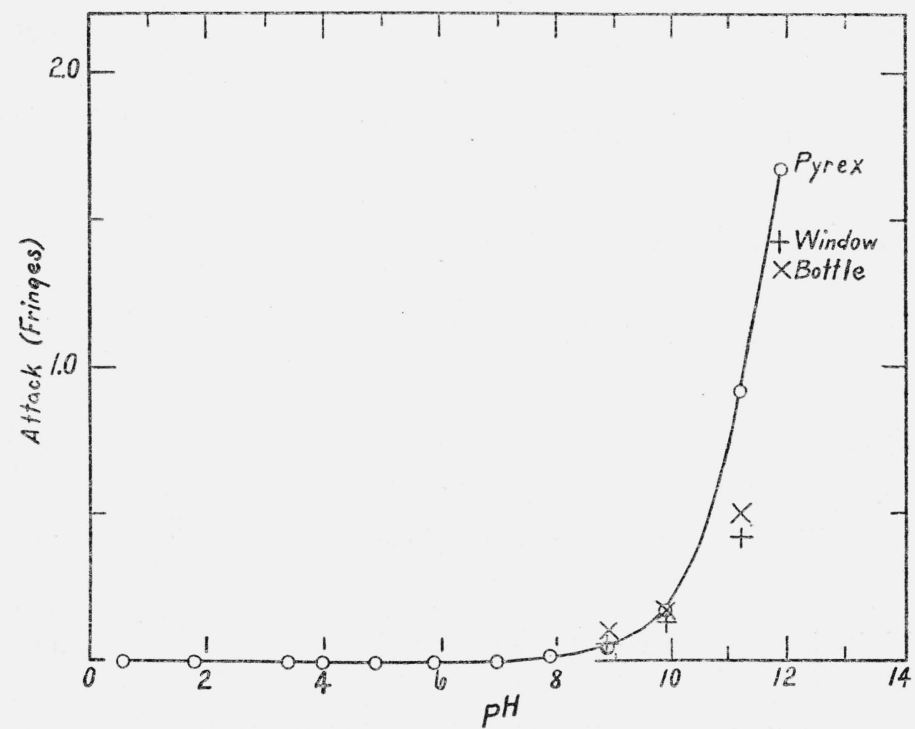

Figure 4.-Attack-pH curve 6 hours at $80^{\circ} \mathrm{C}$ for three glasses which gave no detectable aitack in the acid range from $\mathrm{pH} 0.65$ to $\%$.

Beyond $\mathrm{pH} 8$ the glasses are identified by Bottle $(X)$, Window $(+)$, Pyrex $(O)$.

TABLE 4.-Attack values obtained on eight types of glasses exposed for 6 hours at $80^{\circ} \mathrm{C}$ to Britton universal buffer covering $\mathrm{pH}$ range from 1.8 to 11.9

\begin{tabular}{|c|c|c|c|c|c|c|c|c|}
\hline $\mathrm{pH}$ & Plate & Window & $\begin{array}{l}\text { Am. Cer. } \\
\text { Soc. bot- } \\
\text { tle No. } 1\end{array}$ & Corning 015 & M. F. ${ }^{3}$ & $\begin{array}{c}\text { Chemical } \\
\text { Pyrex }\end{array}$ & B. S. C. ${ }^{3}$ & L. B. C.8 \\
\hline 065 & Fringes & Fringes & Fringes & Fringes & Fringes & Fringes & Fringes & Fringes \\
\hline $\begin{array}{l}0.00 \\
1.8 \\
3.4\end{array}$ & 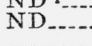 & ND & IVD & $3 \mathrm{~S}_{0-}=$, swelling & $D^{2}$ & ND & $D^{1 / 10}$ & $D^{1 / 2}$ \\
\hline $\begin{array}{l}0.4 \\
4.0\end{array}$ & ND & ND & $\mathrm{ND}$ & $\begin{array}{l}\text { 410-, swemng - } \\
210-\text {, swelling }\end{array}$ & & ND & & \\
\hline 4. & ND. & ND & --- & $2 / 10-$, swelling & $1 / 10$ & ND & $\mathrm{D}$ & \\
\hline $\begin{array}{l}5.9 \\
7.0\end{array}$ & $>_{\text {forpH }}$ & $\begin{array}{l}\text { ND } \\
\text { ND }\end{array}$ & ND & $\begin{array}{l}\text { 310-, swelling } \\
\mathrm{D} \text {, slight surface cut.-. }\end{array}$ & $1-$ & $\begin{array}{l}\text { ND } \\
\text { ND }\end{array}$ & $\begin{array}{l}1 / 10+ \\
1 / 4-\end{array}$ & $2+, \frac{3 / 4}{<}$ \\
\hline $\begin{array}{l}7.9 \\
8.9\end{array}$ & $D^{5 .}$ & $1 / 10-$ & $1 / 10$ & D, surface cut $310-$ & $1 / 4-$ & $\mathrm{D}$ & $\begin{array}{l}1 / 4+ \\
1 / 4-\end{array}$ & $1+$ \\
\hline $\begin{array}{l}0 . \\
9 .\end{array}$ & $1 / 4=$ & $\begin{array}{l}1 / 10- \\
1 / 10+\end{array}$ & $1 / 10$ & $\begin{array}{l}1 / 10-, \text { surace cut } 1 / 2 \\
1 / 4+\end{array}$ & $\begin{array}{l}1 / 4- \\
1 / 4-\end{array}$ & $1 / 4$ & $3 / 4$ & \\
\hline 1 & $1-$ & $1 / 2-$ & $1 / 2$ & $1-\ldots$ & $1 / 2-$ & $1-$ & $1 \frac{1}{4}-$ & 1 \\
\hline 11. & $13 / 4-$ & $11 / 2-$ & $11 / 4+$ & $13 / 4,2-\ldots$ & $1-$ & $13 / 4$ & $13 / 4$ & $13 / 4+$ \\
\hline
\end{tabular}

$1 \mathrm{ND}$, not detectable.

$2 \mathrm{D}$, detectable.

M. F.; B. S. C.; and L. B. C. are optical glasses: medium flint, borosilicate crown, and light barium crown, respectively.

The plate glass is detectably attacked in the vicinity of neutrality with a noticeable improvement in durability at $\mathrm{pH} 9$, after which the rate of attack increases rapidly with further increase in alkalinity (fig. 5). This durability weakness near neutrality is of interest since 
the same thing is shown to a most pronounced degree by the three optical glasses tested (fig. 5).

It should be pointed out also that the chemical durability of a glass to any one reagent cannot be taken as a reliable indicator of its durability to another. For example, the attack on these three optical glasses by the universal buffer in the vicinity of neutrality is very large compared with the attack by distilled water. The latter even after 24 hours at $80^{\circ} \mathrm{C}$ shows an attack of less than $1 / 10$ fringe.

Another commercial glass, Corning 015 [13], which has been used so successfully for glass electrodes, exhibits a slight uniform swelling between $\mathrm{pH} 2$ and 7 , followed by the pronounced attack character-

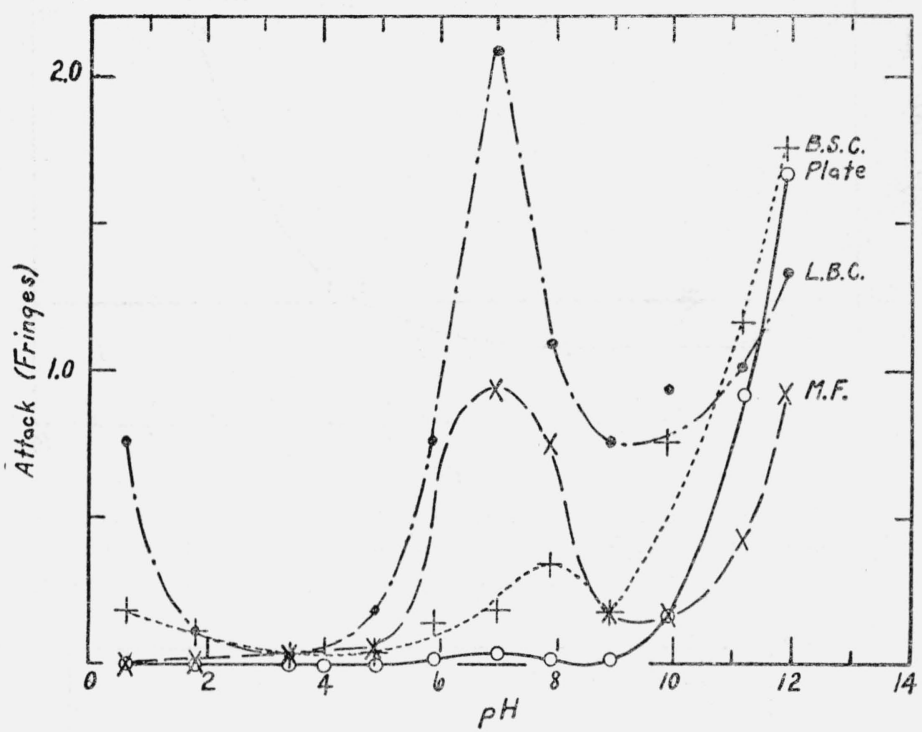

Figure 5.-Attack-pH curves for a plate glass (O) and three optical glasses, borosilicate crown $(+)$, medium fint $(X)$, and light barium crown $(\bullet)$, showing marked attacks in the region of neutrality after 6 hours' exposure at $80^{\circ} \mathrm{C}$.

istic of silicate glasses at alkalinities above $\mathrm{pH} 9$ (table 4, fig. 6), while in the "super acid" region the swelling is repressed with increasing acid concentration [4] (see fig. 7). The durability characteristics of this glass are particularly interesting, (a) because of the correspondence which the regions of durability change bear to regions of established voltage departures of the glass electrode $[13,4]$, (b) because this glass is unique among the types investigated, and (c) because of the implications from the pronounced swelling in the acid region. This swelling is probably caused by a preferential solution of certain constituents of the glass, with the resulting glass surface becoming increasingly rich in silica content.

Jones and Homer [16] have found this enrichment in silica content of the surface of optical glasses in the acid region and have found that the resulting surface layer, when of the proper thickness, reduces the reflection of light from this surface, thereby increasing the light transmission of an optical element. The durability curves for the boro- 
silicate and light barium crown glasses (fig. 5) show that a minimum loss of thickness occurs near $\mathrm{pH} 3$. From this and other considerations one would expect this region to be an optimum for producing silicarich surfaces.

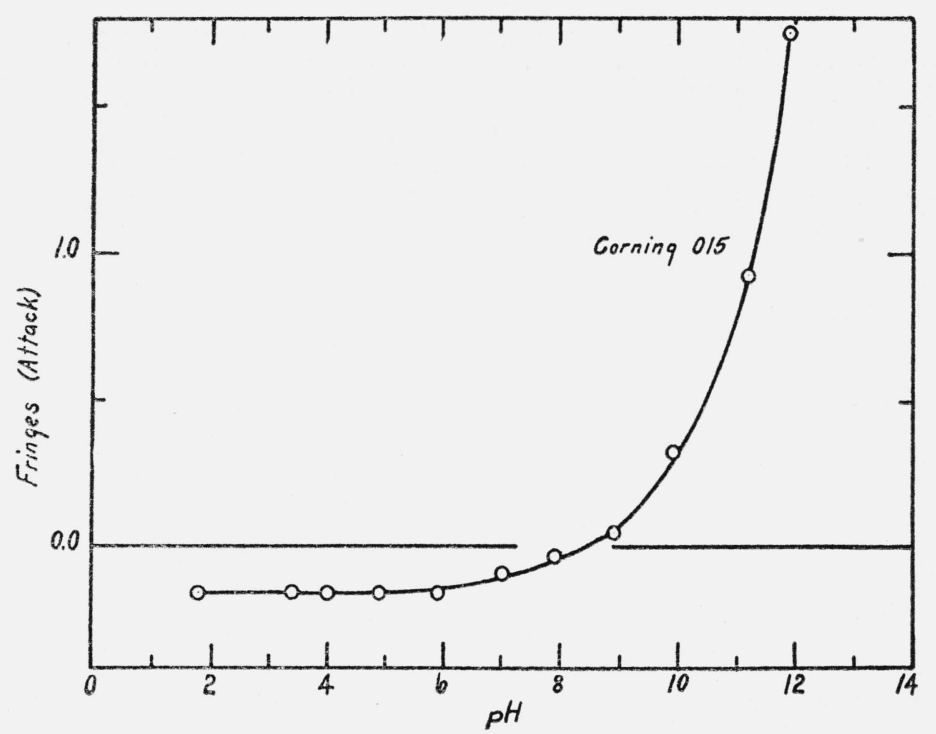

Figure 6.-Attack-pH curve for Corning 015 glass, exposed 6 hours at $80^{\circ} C$ to Britton universal buffer mixtures covering the range $\mathrm{pH} 2$ to 12 .

Region of swelling is plotted as negative attack. Reproduced from figure 1, RP1187.

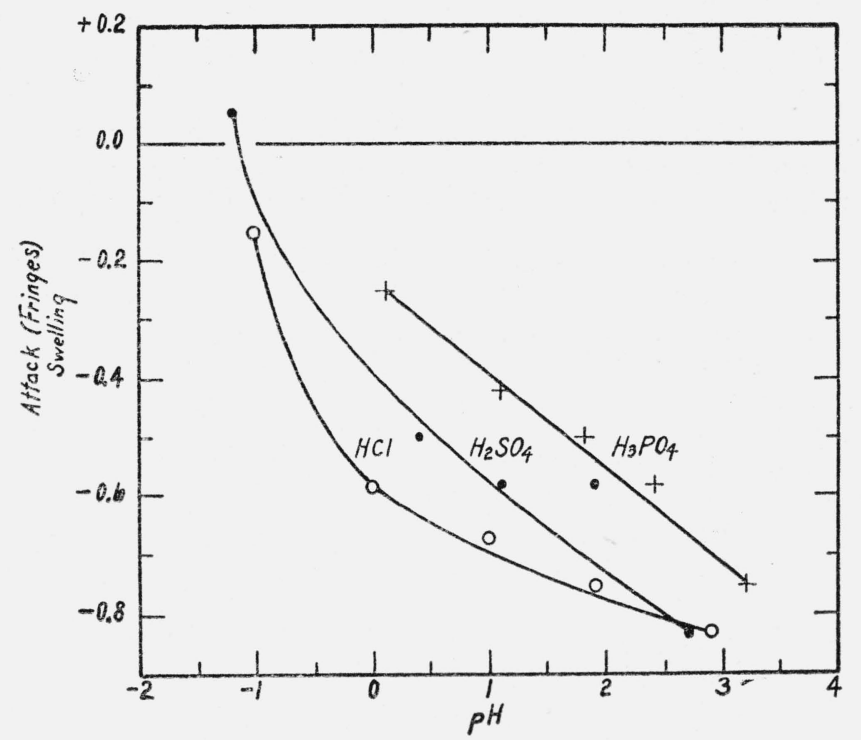

FIGURE 7.-Repression of swelling of Corning 015 glass by increasing concentrations of $\mathrm{HCl}(\mathrm{O}), \mathrm{H}_{2} \mathrm{SO}_{4}(\bullet)$, and $\mathrm{H}_{3} \mathrm{PO}_{4}(+)$, for 48 hours at $80^{\circ} \mathrm{C}$. 
For the Corning 015 glass, attack by distilled water and by the universal buffer near neutrality both cause a small but appreciable swelling. This qualitative agreement of the effect of these two reagents on 015 glass is in extreme contrast to their respective action on the optical glasses.

\section{EFFECT OF INCREASED SODIUM-ION CONCENTRATION ON CHEMICAL DURABILITY}

The voltage departure of the glass electrode in the alkaline region is increased at any fixed $\mathrm{pH}$ and temperature by increasing the sodium-ion concentration [13]. In the light of previous experiments

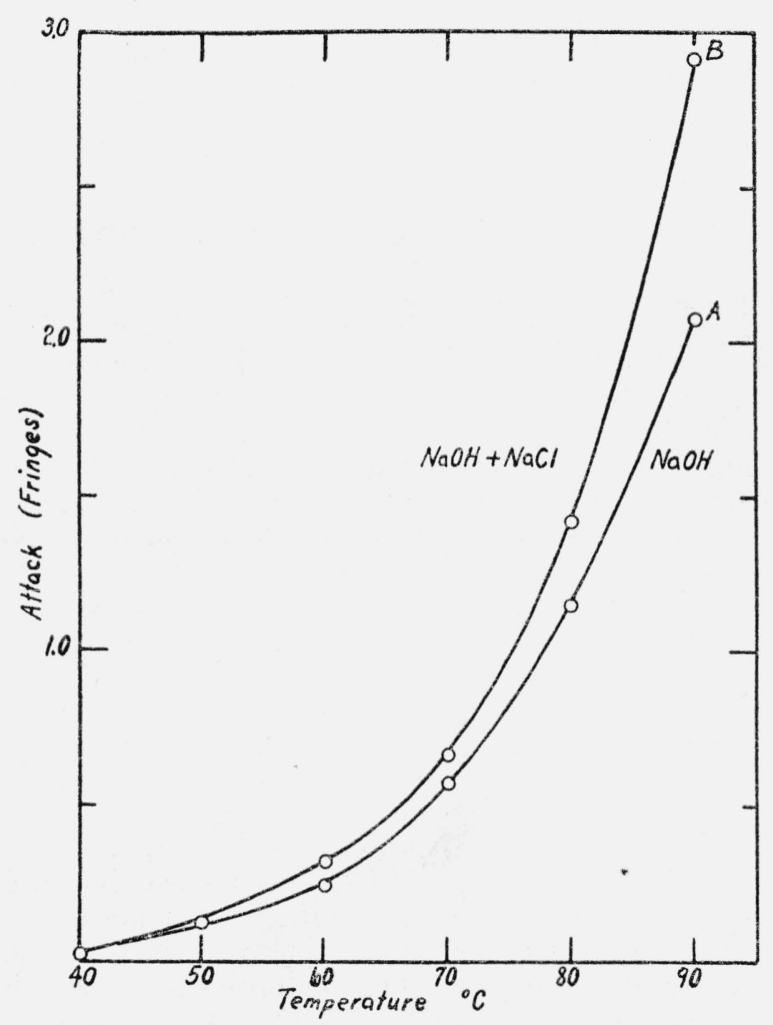

Figure 8.-Altack observed after 3 hours' exposure to 5-percent $\mathrm{NaOH}$ solution, $A$; and 5-percent $\mathrm{NaOH}$ plus an equivalent amount of $\mathrm{NaCl}, B$.

made on voltage departures and durability of the electrode glass [4], it was logical to conclude that additional attack occurs in the presence of increased sodium-ion concentration. To test the validity of this conclusion, samples of an electrode glass were subjected to the action of 5-percent $\mathrm{NaOH}$ held at various temperatures for 3 hours; other samples of the same glass were similarly treated with 5-percent $\mathrm{NaOH}$ to which an equivalent quantity of $\mathrm{NaCl}$ had been added. The results of these two series are given in table 5 and plotted as curves $A$ and $B$, respectively, in figure 8 . The additional attack 
caused by the increased sodium-ion concentration is in qualitative accord with that expected from the voltage departures of the glass electrode.

TABLE 5.-Attacks obtained on a commercial glass from which successful electrodes were made, after 3 hours' exposure to 5-percent $\mathrm{NaOH}$, and 5-percent $\mathrm{NaOH}$ plus an equivalent amount of $\mathrm{NaCl}$

\begin{tabular}{|c|c|c|}
\hline Temperature & $\begin{array}{c}\text { 5-percent } \\
\mathrm{NaOH}\end{array}$ & $\begin{array}{c}\text { 5-percent } \\
\text { NaOH plus } \\
\text { equivalent } \\
\mathrm{NaCl}\end{array}$ \\
\hline $\begin{array}{c}{ }^{\circ}{ }^{C} \\
40 \\
50\end{array}$ & $\begin{array}{l}\text { Fringes } \\
D 1 \\
1 / 10+ \\
1 / 4 \\
1 / 2+ \\
11 / 4- \\
2+\end{array}$ & $\begin{array}{l}\text { Fringes } \\
D 1 \\
1 / 10+ \\
1 / 4+ \\
3 / 4- \\
11 / 2- \\
3-\end{array}$ \\
\hline
\end{tabular}

$1 \mathrm{D}$, detectable.

\section{COMPARISON WITH RESULTS OBTAINED BY ANOTHER METHOD}

Durability tests of a number of chemical-ware glasses have been made by Wichers, Finn, and Clabaugh [15]. Their method involved determination of the loss in weight of 250-ml Erlenmeyer flasks whose inner surfaces had been subjected to the boiling reagent for a given time. In order to determine whether or not their results agree with those obtained by the interferometer method, comparative tests were made on four commercial glasses used in the manufacture of chemical ware, which were exposed to $0.05 \mathrm{~N}$ and $0.5 \mathrm{~N} \mathrm{NaOH}$ for 3 and 6 hours at $80^{\circ} \mathrm{C}$. Wichers, Finn, and Clabaugh tested three of these glasses with the same solutions. The data obtained by the interferometer method are recorded in table 6 and plotted in figure 9. The order of decreasing durability found for $0.5 \mathrm{~N} \mathrm{NaOH}$ agrees with that determined by Wichers, Finn, and Clabaugh and was as follows: Kimble N-51-a, Tamworth (new Glasbake), Pyrex and Tamworth (old). ${ }^{2}$ However, the interferometer method was not sufficiently sensitive to detect attack on any of the four glasses exposed 24 hours at $80^{\circ} \mathrm{C}$ to $\mathrm{N} \mathrm{H}_{2} \mathrm{SO}_{4}, 5$-percent $\mathrm{NaCl}$ solution, or distilled water (table 6), while Wichers, Finn, and Clabaugh were able to detect very small durability differences for these different makes of glassware to these solutions. The greater sensitivity of their method can be

- attributed largely to two factors: (1) the large surface which they used and (2) the elevated temperature. With a temperature of slightly over $100^{\circ} \mathrm{C}$, their attack per unit area should be approximately four times that for the $80^{\circ} \mathrm{C}$ used in the interferometer method.

Prolonged exposures of these four glasses and one bottle glass to $N \mathrm{H}_{2} \mathrm{SO}_{4}$, 5-percent $\mathrm{NaCl}$, and distilled water at $80^{\circ} \mathrm{C}$ gave the results listed in table 6 . A very interesting feature of the acid attack for 7 days at $80^{\circ} \mathrm{C}$ is that the samples of Pyrex and Tamworth tested showed less resistance to $\mathrm{N}_{2} \mathrm{SO}_{4}$ than did the American Ceramic Society Bottle Glass No. 1 [11]. Such results should be given further attention. They indicate that the borosilicate laboratory glasswares

${ }_{2}$ The terms "old" and "new" are used to distinguish between a Tamworth glass previously marketed and the product whose analysis is given in the publication by Wichers, Finn, and Clabaugh [15]. 
possibly do not possess the superior acid resistance that has been accredited to them in the past. The only alternate interpretation of the results is the possibility that the bottle glass may have yielded data which were more favorable than its actual chemical resistance. This could conceivably have occurred through a simultaneous solution and swelling at rates which just counterbalanced each other, but the probability of such a coincidence seems slight.

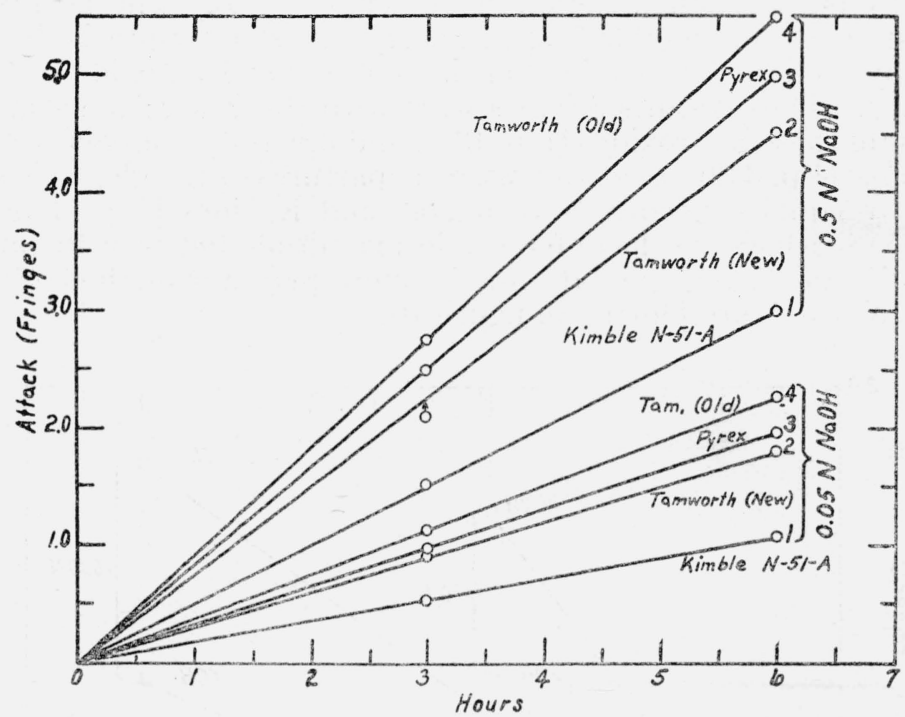

FIGURE 9.-Comparison of the durability of four glasses used in the manufacture of chemical glassware, to $0.05 \mathrm{~N}$ and $0.5 \mathrm{~N} \mathrm{NaOH}$ at $80^{\circ} \mathrm{C}$.

1. Kimble N-51-A.

2. Tamworth (New).

3. Pyrex.

4. Tamworth (Old).

TABLE 6.-Durability measurements made at $80^{\circ} C$ on four glasses used in the manufacture of chemical laboratory glass and one bottle glass

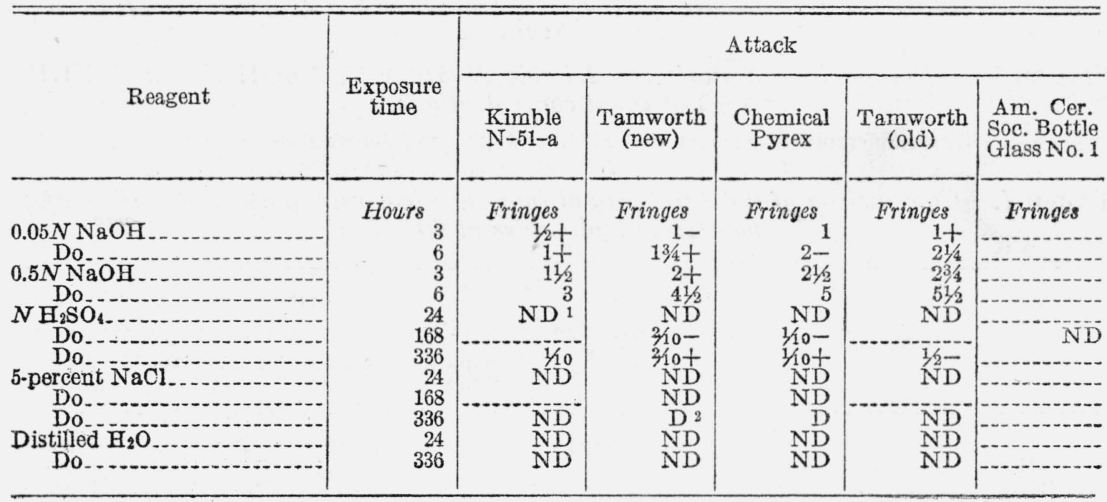

$1 \mathrm{ND}$, not detectable.

D, detectable. 


\section{COMPARISON OF DURABILITY IN THE PRESENCE OF SODIUM AND POTASSIUM HYDROXIDES}

An oral report that burettes were more strongly attacked by aqueous $\mathrm{KOH}$ than by $\mathrm{NaOH}$ led to a preliminary investigation of the durability of these same four chemical-ware glasses to $0.1 \mathrm{~N}$ and $1.0 \mathrm{~N}$ solutions of these hydroxides. The solutions were prepared from freshly opened bottles of $\mathrm{NaOH}$ and $\mathrm{KOH}$ and standardized against potassium acid phthalate without attempting to remove $\mathrm{CO}_{2}$. The results obtained are recorded in table 7 , and in every case show appreciably more attack by sodium hydroxide than by potassium hydroxide of equal normality. These results are in accord with the generally recognized behavior of these hydroxides [1, p. 132], and are also in agreement with predictions [4 p. 342] based on voltage departures of the glass electrode caused by equal concentrations of $\mathrm{Na}^{+}$and $\mathrm{K}^{+}$ions [14]. For convenience in visualizing the difference in magnitude between the attack by $\mathrm{NaOH}$ and $\mathrm{KOH}$, the data for the more resistant of these glasses, Kimble $\mathrm{N}-51-\mathrm{A}$ are plotted in figure 10.

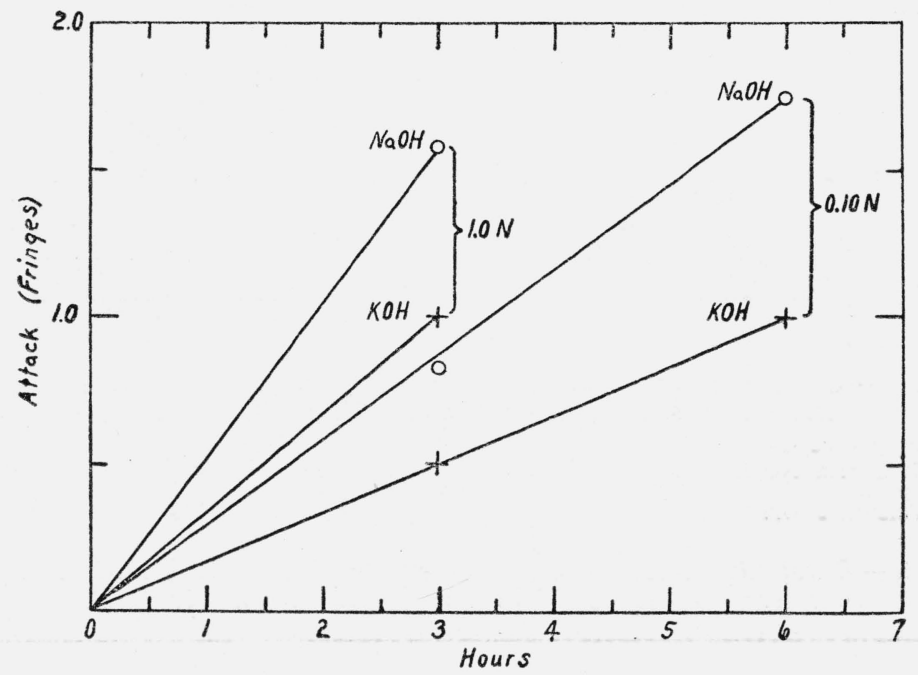

FIGURE 10.-Comparison of attacks on Kimble $N-51-A$ by $\mathrm{NaOH}(\mathrm{O})$ and $\mathrm{KOH}$ $(+)$ of equal concentrations.

These differences are characteristic of all the four chemical-ware glasses tested.

TABLE 7.-Comparison of the durability of four chemical-ware glasses to sodium and potassium hydroxides at $80^{\circ} \mathrm{C}$

\begin{tabular}{|c|c|c|c|c|c|}
\hline \multirow{2}{*}{ Reagent } & \multirow{2}{*}{$\begin{array}{c}\text { Exposure } \\
\text { time }\end{array}$} & \multicolumn{4}{|c|}{ Attack } \\
\hline & & $\begin{array}{c}\text { Chemical } \\
\text { Pyrex }\end{array}$ & $\begin{array}{l}\text { Kimble } \\
\text { N-51-a }\end{array}$ & $\underset{\text { (old) }}{\text { Tamworth }}$ & $\begin{array}{c}\text { Tamworth } \\
\text { (new) }\end{array}$ \\
\hline $\begin{array}{l}N \mathrm{NaOH} \\
N \mathrm{KOH} \\
0.10 N \mathrm{NaOH} \\
0.10 \mathrm{~K} \mathrm{~K}_{\mathrm{NaOH}} \\
0.10 \mathrm{~N} \mathrm{KOH}\end{array}$ & $\begin{array}{r}\text { Hours } \\
3 \\
3 \\
3 \\
3 \\
6 \\
6\end{array}$ & $\begin{array}{l}\text { Fringes } \\
21 / 2 \\
11 / 2+ \\
11 / 4+ \\
1+ \\
23 / 4 \\
2+\end{array}$ & $\begin{array}{c}\text { Fringes } \\
11 / 2+ \\
1 \\
3 / 4+ \\
1 / 2 \\
13 / 4 \\
1\end{array}$ & $\begin{array}{c}\text { Fringes } \\
23 / 4+ \\
2- \\
11 / 2 \\
11 / 4- \\
3 \\
21 / 4\end{array}$ & $\begin{array}{c}\text { Fringes } \\
21 / 4 \\
11 / 2+ \\
11 / 4- \\
1+ \\
21 / 4 \\
2\end{array}$ \\
\hline
\end{tabular}




\section{SUMMARY}

The interferometer method for determining the chemical durability of glass has been applied over an extended range of conditions to a wide variety of glasses. The results obtained show that it is capable of giving useful data under conditions in which the more conventional methods are not applicable.

The authors are indebted to A. N. Finn for his helpful suggestions during the progress of this investigation.

\section{REFERENCES}

[1] George W. Morey, The properties of glass, American Chemical Society Monograph No. 77, p. 103-134. (Reinhold Publishing Corporation, 330 West 42 d St., New York, N. Y., 1938.)

[2] Relative durability of optical glass. Tech. News Bul. NBS 221, 88 (Sept. 1935).

[3] E. Berger, Grundsätzliches über die chemische Angreifbarkeit von Gläsern I, Glastech. Ber. 14, 351 (1936).

[4] Donald Hubbard, Edgar H. Hamilton, and Alfred N. Finn, Effect of the solubility of glass on the behavior of the glass electrode, J. Research NBS R2, 339-349 (1939) RP1187.

[5] V. W. Geffcken and E. Berger, Grundsätzliches über die chemische Angreifbarkeit von Gläsern II, Glastechn. Ber. 16, 296-304 (1938).

[6] F. H. Getman and F. Daniels, Outline of theoretical chemistry, 5th ed., p. 336 (John Wiley and Sons, Inc., New York, N. Y., 1931).

[7] R. L. Müller and C. V. Weinstein, Untersuchung der Lösungsgeschwindigkeit von Alkaliborgläsern, Acta Physicochem. U. R. S. S. 3, 465-502 (1935).

[8] Edgar H. Hamilton and Donald Hubbard, Titration and conductivity measurements of aqueous extracts from bottles (work not yet published).

[9] W. C. Taylor and R. D. Smith, Solubility characteristics of glasses basically different in composition. J. Am. Ceram. Soc. 19, 331 (1936).

[10] T. S. Britton, Hydrogen ions, 2d ed., table 57 (c), p. 225 (D. Van Nostrand and Co., Inc., New York, N. Y. (1932).

[11] Report of Committee on the Chemical Durability of Glass, Bul. Am. Ceram. Soc. 14, 181 (1935).

[12] P. H. Walker and F. W. Smither, Comparative tests of chemical glassware, J. Ind. Eng. Chem. 9, 1090-1092 (1917).

[13] D. G. MacInnes and M. Dole, The behavior of glass electrodes of different compositions, J. Am. Chem. Soc. 52, 29-36 (1930).

[14] D. G. MacInnes and D. Belcher, Further studies on the glass electrode, J. Am. Chem. Soc. 53, 3315-3331 (1931).

[15] Edward Wichers, A. N. Finn, and W. Stanley Clabaugh, Comparative tests of chemical glassware, J. Research NBS 26, 537 (1941) RP1394.

[16] Frank L. Jones and Howard J. Homer, Chemical methods for increasing the transparency of glass surfaces, J. Opt. Soc. Am. 31, 34-37 (1941).

Washington, June 17, 1941. 